\title{
WATER FOR WESTERN ENERGY DEVELOPMENT UPDATE 1977
}

\section{SEPTEMBER, 1977}

\section{WESTERN STATES WATER COUNCIL \\ Suite $\mathbf{2 0 0}$ \\ Chancellor Building \\ 220 South 2nd East \\ Salt Lake City, Utah 84111}

Tucson Myers and Associates, Inc.
246 Peach St.
Silverton, Oregon 97381 


\section{DISCLAIMER}

This report was prepared as an account of work sponsored by an agency of the United States Government. Neither the United States Government nor any agency Thereof, nor any of their employees, makes any warranty, express or implied, or assumes any legal liability or responsibility for the accuracy, completeness, or usefulness of any information, apparatus, product, or process disclosed, or represents that its use would not infringe privately owned rights. Reference herein to any specific commercial product, process, or service by trade name, trademark, manufacturer, or otherwise does not necessarily constitute or imply its endorsement, recommendation, or favoring by the United States Government or any agency thereof. The views and opinions of authors expressed herein do not necessarily state or reflect those of the United States Government or any agency thereof. 


\section{DISCLAIMER}

Portions of this document may be illegible in electronic image products. Images are produced from the best available original document. 


\section{PREFACE}

In 1974, the Western States Water Council issued its first report regarding water requirements for energy. Notable at that time were indications of significant future Western water demands for large oil shale processing and a number of coal gasification facilities, coupled with substantial water needs for steam-electric generation facilities planned to meet electrical demands, as electricity use was expanding at about seven percent per year.

Since 1974, the Council has observed a change in those indications and future water for energy needs now appear to be smaller. Oil shale and coal gasification industry plans are in essence indefinite, at least prior to 1990, and steam-electric generation development is now planned to occur at a slower rate, to meet a reduced electrical demand growth of now projected rates between three and five percent per year. These abrupt changes, resulting in part from inconsistent Federal energy policies, justify review and presentation of current concepts of water needs for western energy development.

The Council felt also that a review and analysis of ways to conserve water in energy processes would be important and timely. Many independent studies have looked at water demands and potential water saving practices in isolated energy processes, but the impact Westwide of conservation practices was not known.

The council contracted with Tucson Myers and Associates, Inc., who in association with L. E. Wilkinson, prepared data and draft text. This document, then, is a product of the consultant's effort, review and comment by the Council's Water Resources Committee, and approval of the Western States Water Council.

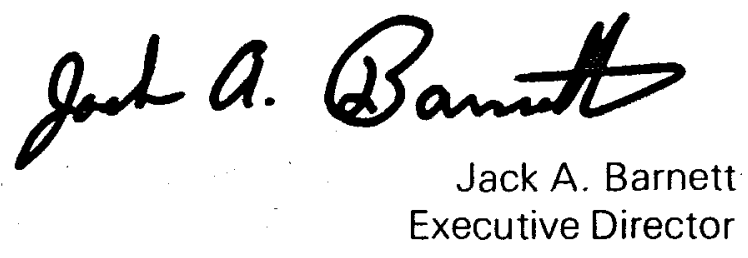




\section{TABLE OF CONTENTS}

PREFACE

I. SUMMARY AND CONCLUSIONS 1

II. NEED FOR WATER 2

A. Update of 1974 Energy Production Projections 2

1. Projected Load Demands 2

2. Facilities and Processes 5

a. General Considerations 5

b. Coal Slurry Pipelines 5

c. Coal Gasification and Liquifaction Plants 6

d. Steam-Electric Generation Plants 6

3. Steam-Electric Plant Cooling Water Consumption 8

III. WATER USE CONSIDERATIONS IN ENERGY DEVELOPMENT 17

$\begin{array}{ll}\text { A. Economic Considerations in Plant Cooling } & 17\end{array}$

B. Alternative Water Supplies 18

C. Institutional Considerations 18

$\begin{array}{ll}\text { 1. State Water Law } & 18\end{array}$

2. State Siting Practices 20

3. Environmental Considerations 20

D. Water Conservation Opportunities 21

APPENDICES 23 


\section{LIST OF FIGURES}

II-1 Historic Electric Load Growth in U.S.

II-2 Total Energy Use and Total Electrical Demand

Projected for Western U.S.

II-3 Routing of Existing, Proposed and Planned CoalSlurry Pipelines

II-4 Location of Existing and Planned SteamElectric Power Plants

II-5 Shift from Nuclear Towards Coal-Fired Plants for Thermal Electric Generation

II-6 Essential Components of Steam-Electric Plants

1I-7 Trends in Cooling System Selections for Thermal Electric Power Plants in WSWC Region 


\section{LIST OF TABLES}

Page

II-1 Electrical Energy Production and Consumption in Western States

II-2 Potential Coal-Slurry Pipelines Originating in WSWC Member States

II-3 Water Consumption Rates for Various Energy Processes

II-4 State Summary - Consumptive Use by Steam-Electric Generation Existing as of 1976

II-5 State Summary - Consumptive Use by Planned Steam-Electric Generation 1977 to 1986

II-6 Consumptive Use By Planned Steam-Electric Generation Facilities in WSWC Region to 1990

\section{APPENDIX A}

A-1 WSWC Region Existing Oil and Gas-Fired Electrical Generation Plants

A-2 WSWC Region Existing Coal-Fired Electrical Generation Plants

A-3 WSWC Region Existing Nuclear Electrical Generation Plants

\section{APPENDIX B}

B-1 WSWC Region Planned Oil and Gas-Fired Electrical Generation Plants

B-2 WSWC Region Planned Coal-Fired Electrical Generation Plants

B-3 WSWC Region Planned Nuclear Electrical Generation Plants 


\section{SUMMARY AND CONCLUSIONS}

This report contains projections of steamelectric plants and other energy production developments in the West to 1990 and presents findings in regard to their estimated water requirements. Important institutional considerations and water conservation opportunities relating to western energy development also are examined.

National load growth is expected to be between 3 and 5 percent per year (p. 2 ) and is expected to reach a total demand of 170 quads by the year 2000 (p. 2 ). Western energy consumption will total about 25 quads over the same period (p. 2 ), about half of which will be electrical energy ( $p$. 21.

By 1990, oil shale processing may be barely started, geothermal development will be small, and only two coal gasification facilities are planned (p. 6 ). Five coal slurry pipelines are planned with a total water requirement of $46,000 \mathrm{AcFt} / \mathrm{yr}$ to transport 59 million tons per year (p. 6 ).

Firm plans exist among Western utilities to construct 85 additional large steamelectric generating units in 46 locations, with an aggregate capacity of $46,189 \mathrm{MW}$ (p. 6 ).

Total freshwater consumption for existing and planned steam-electric generation plants to 1986 will total $885,000 \mathrm{AcFt} / \mathrm{yr}$, an increase of $588,000 \mathrm{AcFt} / \mathrm{yr}$ (p. 13 ). An estimated additional 15,000 $\mathrm{MW}$ installed between 1986 and 1990 will increase consumption by $240,000 \mathrm{AcFt} / \mathrm{yr}$. Total increased consumption of $828,000 \mathrm{AcFt} / \mathrm{yr}$ over present levels compares to $1,337,000$ AcFt/yr estimated for the same purpose in the Council's 1974 report (p.13).

Use of once-through cooling, the least expensive method of plant cooling with respect to both investment and water consumption, will not be predominant ( $p$. 13). Evaporative cooling is becoming the most prevalent system, although it is the largest water user (p.13). Both wet-dry and dry systems are being planned for a few installations, although higher in cost (p.13).

Evaporative cooling systems are attractive until water costs exceed $\$ 660$ per Ac. Ft. Wet/Dry systems are feasible till water costs exceed $\$ 4,200$ (p. 17). Purchase of irrigated farm lands results in water costs of about $\$ 90$ to $\$ 160$ per .Ac. Ft. (p. 17).

Western agriculture will not be able to compete in the open market place with the energy industry for water supplies, although agricultural interests could participate in cost sharing of joint use facilities (p.17).

Two pilot projects are under way to determine feasibilities of use of treated return flows (p. 18 ).

State water institutions can accommodate future energy development. State water law provides for acquisition of water supplies for energy production ( $p$. 181. Many Western states siting laws include provisions whereby opportunities exist for planning multiple purpose water developments in conjunction with needed new energy facilities (p. 20 ).

Up to 75,000 AcFt/yr could be conserved by 1990 , if energy conservation measures result in a one percent reduction in electrical load growth (p. 21 ). If ten of the 85 additional plants scheduled by 1986 were to be converted to once-through cooling, instead of evaporative systems now planned for, up to $100,000 \mathrm{AcFt} / \mathrm{yr}$ would be conserved (p. 21). A possibility exists for use of once through cooling without significant environmental degradation (p. 21). 


\section{NEED FOR WATER}

\section{A. Update of 1974 Energy Production Projections}

\section{Projected Load Demands}

Electrical load growth for the nation has been 7 percent per year for the period 1955 to 1973 . The recession that was prompted by the OPEC oil embargo late in 1973 altered energy use patterns and contributed to a new round of price escalation which in turn affected energy consumption. Current estimates are that national electrical load growth will continue over the next 10 to 20 years but at a reduced rate of between 3 and 5 percent per year. Figure II-1 shows electrical energy demands over the past six years.

Numerous projections of electrical loads have been made. Using Bureau of Census predictions of a United States population of 263 million persons by the year 2000, with 96 percent employment, the Electric Power Research Institute (EPRI), the research arm of utilities in the United States, has projected an energy requirement of 170 quads. 1 The Bureau of Economic Analysis has projected a Gross National Product (GNP) of over \$2 trillion by the year 2000; and EPRI, noting the near linear relationship between energy consumption and GNP over a 90 year period, calculates the resulting energy need at 180 quads. Current predictions by the U.S. Bureau of Mines2 show a national energy need of 163 quads by the year 2000. EPRI predicts the portion of U.S. energy consumed as electrical energy will range between 43 and 63 percent, depending on electrification of transportation.

The West, with 17 percent of the nation's

1Quad - 1015 BTU

- 175 million barrels of oil (Bbl)

2Bureau of Mines, „U.S. Energy Through the Year 2000," Dec. 1975. population, consumes 15 percent of the energy consumed nationwide, according to the Western Interstate Nuclear Board (WINB).3 WINB also has shown, using Federal Power Commission (FPC) data, that the West has been reasonably self-sufficient in electrical energy production. Table II-1 lists electrical energy production and consumption in 1972 for western states.

Based on three major assumptions, WINB recently has examined future energy needs in the West. The assumptions are:

1. National energy needs in the U.S. in the year 2000 will total 170 quads.

2. The relationship between national energy needs and Western energy consumption will remain at 15 percent and the West will continue to "export" energy at the same relative rate.

3. Half the total energy consumed in the West will, by 1990 , be electrical energy.

Figure II-2 illustrates a summary of the foregoing discussion. The upper curve shows total energy use. Reading the right hand ordinate, which measures national energy demands, for the year 2000 shows 29 billion barrels (bbl) of oil. At 5.8 million $\mathrm{BTU} / \mathrm{Bbl}$, and $1015 \mathrm{BTU} /$ quad, national energy demand is 170 quads. Using the left hand ordinate, which measures Western energy demands, values are 15 percent of those on the right hand, national, side, giving a value of about 4,400 million $\mathrm{Bb}$ for the year 2000. Applying the same conversion factors results in a Western states energy demand of about 25 quads in the year 2000.

The curve labeled 'Total Electrical Demand - West Only' is a plot of historic electrical demands from 1950 to 1975 . The period 1975 to 1985 is a forecast by Western Systems Coordinating Council (WSCC) and the period 1985 to 2000 is a projection by

3Western States Energy Resource Development Update, 1976, L.E. Wilkinson for Western Interstate Nuclear Board, Sept. 1976. 
Figure II-1

Historic Electric Load Growth in U.S.

Source: Electric Power Statistics-1976

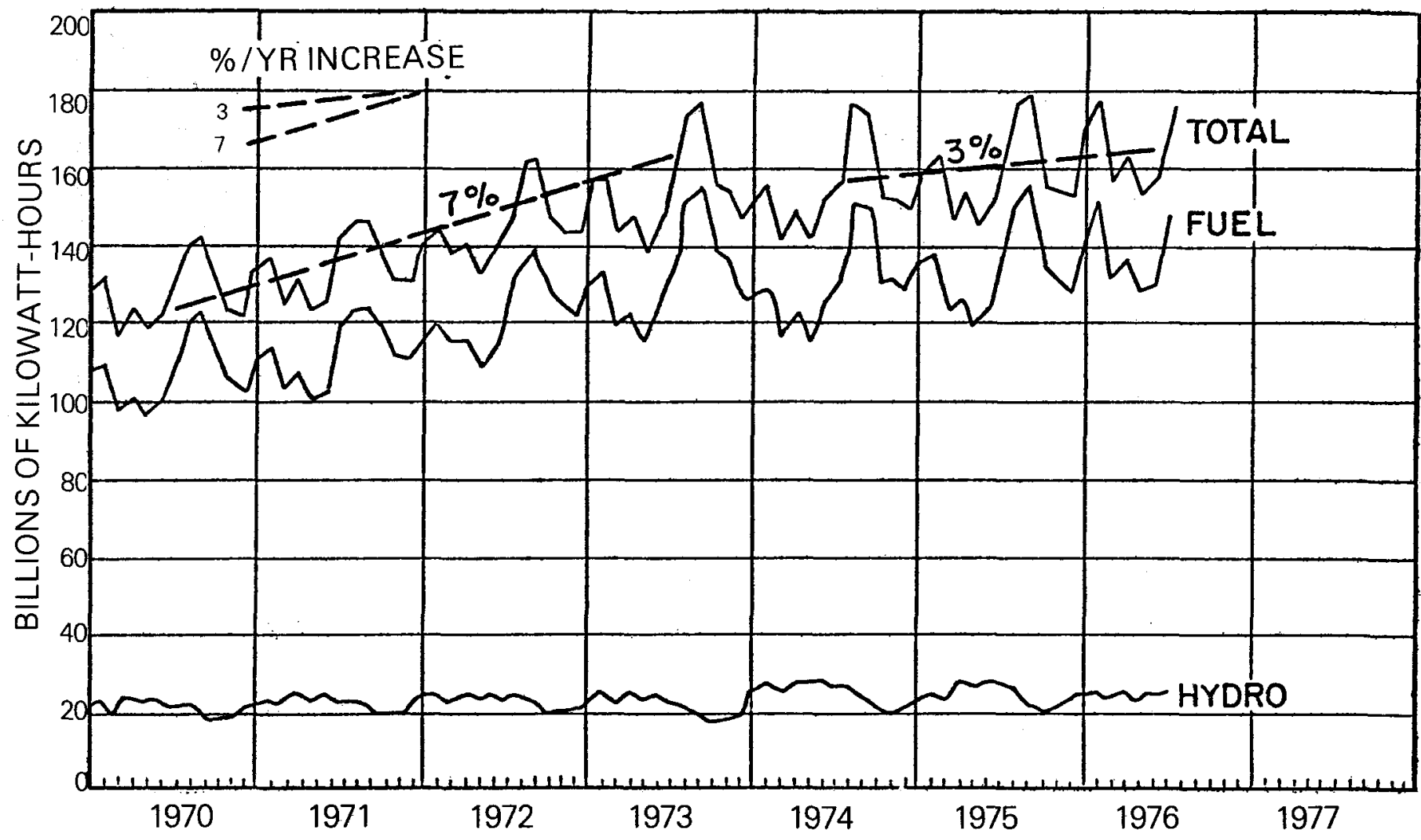

TABLE II-1

ELECTRICAL ENERGY PRODUCTION AND CONSUMPTION IN WESTERN STATES $(1,000,000 \mathrm{KW}-\mathrm{HR})$

\begin{tabular}{|c|c|c|c|c|c|c|c|}
\hline State & $\begin{array}{c}\text { Elect. } \\
\text { Consumptiona }\end{array}$ & $\begin{array}{c}\text { Gross } \\
\text { Productiona }\end{array}$ & $\begin{array}{c}\text { Net } \\
\text { Productionb }\end{array}$ & $\begin{array}{c}\text { Net } \\
\text { Imports }\end{array}$ & $\begin{array}{c}\text { Net } \\
\text { Exports }\end{array}$ & $\begin{array}{l}\% \text { Consumpt. \% } \\
\text { Imported }\end{array}$ & $\begin{array}{l}6 \text { Production } \\
\text { Exported }\end{array}$ \\
\hline Arizona & 20,280 & 20,532 & 17,863 & 2,417 & & 11.9 & \\
\hline Alaska & 1,624 & 1,860 & 1,618 & 6 & & 0.4 & \\
\hline California & 133,283 & 122,094 & 106,222 & 27,061 & & 20.3 & \\
\hline Colorado & 14,949 & 15,650 & 13,616 & 1,333 & & 8.9 & \\
\hline Idaho & 12,922 & 9,694 & 8,434 & 4,448 & & 34.7 & \\
\hline Montana & 9,169 & 11,055 & 9,618 & & 449 & & 4.7 \\
\hline Nevada & 7,724 & 13,838 & 12,039 & & 4,315 & & 35.8 \\
\hline New Mexico & 7,070 & 20,113 & 17,498 & & 10,428 & & 59.6 \\
\hline Oregon & 30,646 & 35,293 & 30,705 & & 59 & & 0.2 \\
\hline Utah & 7,201 & 4,038 & 3,513 & 3,688 & & 51.2 & \\
\hline Washington & 59,134 & 89,379 & 77,760 & & 18,626 & & 24.0 \\
\hline Wyoming & 4,200 & 10,803 & 9,397 & & 5,197 & & 55.3 \\
\hline Total & 308,202 & 354,349 & 308,283 & 38,993 & 39,074 & & \\
\hline
\end{tabular}




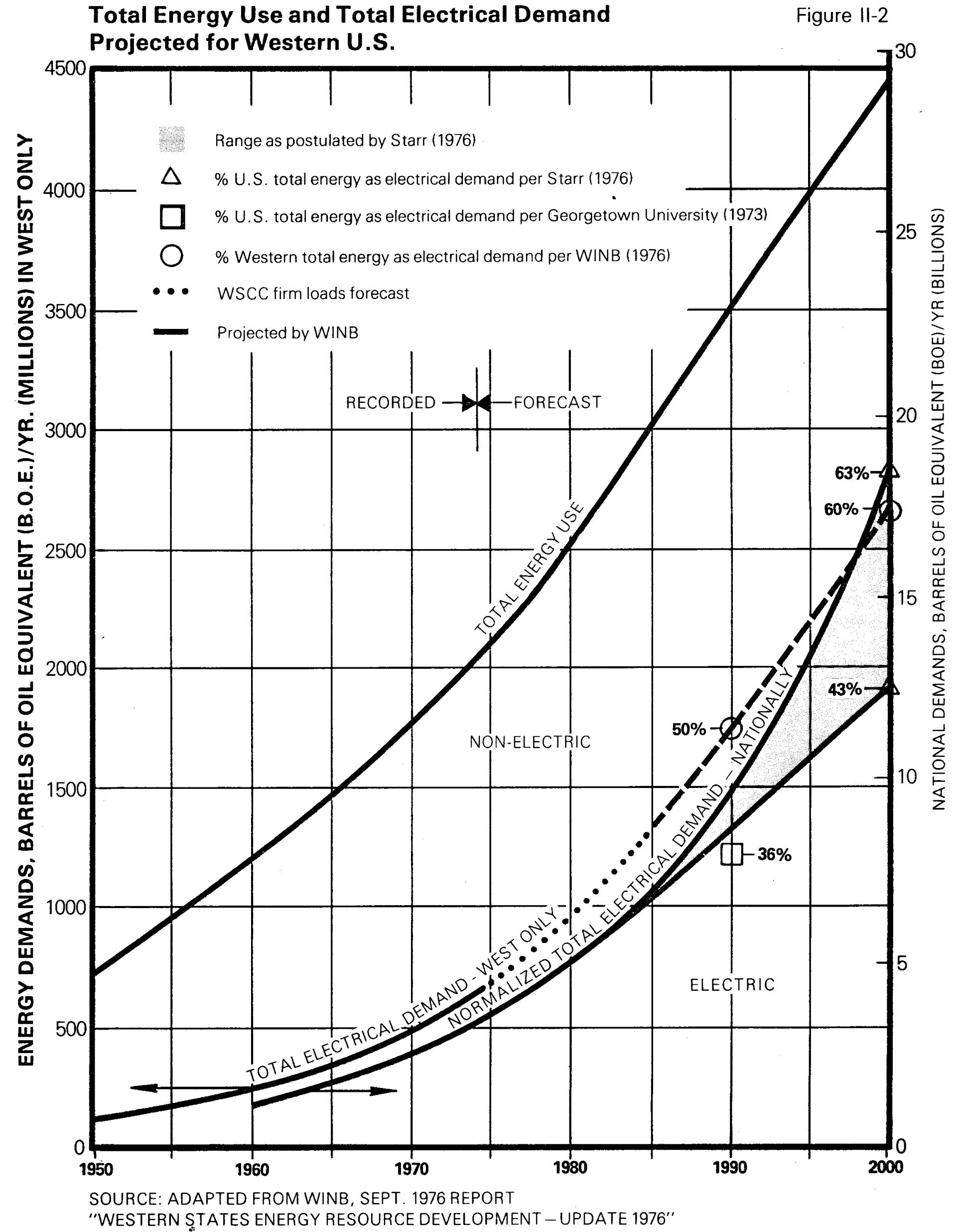


WINB. Values relating to this curve should be read from the left hand ordinate.

The lower curve, labeled 'Normalized Total Electrical Demand - Nationally' is a plot of historic and projected data by EPRI. The shaded area reflects the range of the electrical energy portion of total energy demands.

\section{Facilities and Processes}

a. General Considerations

The 1974 Report of the Western States Water Council, "Western States Water Requirements for Energy Development to 1990 " was prepared just following the OPEC oil embargo. The need for energy independence became clear at that time but not the means for achieving such a goal. For the West, there were visions of a wide range of energy developments including several oil shale recovery plants, 7 geothermal developments, and 18 coal gasification plants, all of which were scheduled to commence before 1990. Current information indicates that by 1990 oil shale development may be barely started, a smaller number of geothermal developments are expected, and only two coal gasification plants are scheduled.

The delay in development of an oil shale industry is a result of the lack of a firm Federal price support policy for the product. It has not been clear to the sponsors of the first oil shale plant how they would be able to compete with oil prices resulting from controlled domestic production. The first plant was to be operational about 1979, but is now "tabled" until "a more favorable political and economic situation" prevails.

Oil shale activities that are continuing tend to be experimental rather than production oriented. The U.S. Bureau of Mines has a project scheduled for the
Piceance Basin region of Colorado for in situ retorting and recovery of vaporized oil. Tar sands processing also is proceeding on an experimental basis in Utah. However, full scale production of oil from shale and tar sands is not likely without currently absent federal incentives. Therefore, no reliable estimates of water requirements for oil shale and tar sands processing between now and 1990 can be prepared. Lead times are such however, that with establishment of a Federal energy policy, oil shale and tar sand processing would probably not commence prior to 1985 and attendent water requirements would still be quite small by 1990.

Geothermal development, likewise, is in too adolescent a position for reasonable predictions to be made of when, where, and how much water will be needed. Thus, geothermal water needs also have been omitted from this report.

The 1974 WSWC report qualified water needs for recovery of natural gas, crude oil, refineries, and strip mine revegetation. These needs are basically unchanged since the 1974 report and are relatively small. This report contains no new projections for these less significant needs and concentrates rather on the major water uses.

The energy processes to be further considered include:

Coal Slurry Pipelines

Coal Gasification and Liquefaction Plants

Thermal Electric Generation Plants

Coal-Fired

Nuclear

Oil and Gas-Fired

b. Coal Slurry Pipelines

Use of slurry pipelines for transportation of coal to plants near load centers has received increasing attention since 1974. Five such projects are now proposed, as 
listed in Table II-2 and shown in Figure II-3, with a water requirement totaling $46,000 \mathrm{Ac}$. Ft./yr. for all five.

\section{TABLE II-2}

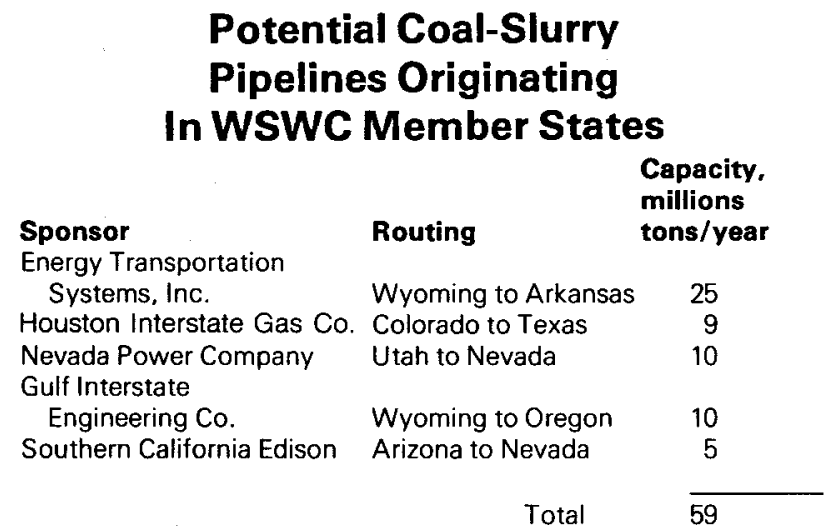

Slurry pipelines can result in less environmental impact than electrical transmission lines along their respective rights of way. Additionally, the estimated water requirement is only about 18 percent of that required for evaporatively cooled plants burning a comparable amount of coal. However, local economies in areas where pipelines originate are affected to nearly the same extent as if a generation plant were also to be constructed without receiving the benefits of large assessed valuations resulting from plant construction. Thus lower water requirements should not be the only concern in the decision making process.

Plans are not definite regarding pipeline construction, however. Coal slurry pipeline proponents are pleading their case for eminent domain authority before congressional committees. Railroad companies strongly oppose federal approval of such authority. The outcome will greatly influence how many proposed pipeline projects actually materialize and their schedules of construction and operation. c. Coal Gasification and Liquefaction Plants Coal gasification and liquefaction plants eventually will be needed to supply natural gas and burnable liquids. Commercial feasibility depends heavily on natural gas pricing policies by FPC. A specific effort was made in the preparation of this report to locate firm plans for coal gasification and liquefaction plants calling for completion prior to 1990. Although many are being considered, none were found to be firmly scheduled. Two plants in the Four Corners area of New Mexico appear likely but plans are far less firm than those for thermal electric plants. Most probably the gas industry will be "tooling up" about 1990 and, as a result, on a regional basis, water needs before then are not likely to be large.

Processes employed for both coal gasification and liquifaction require high temperatures such that opportunities for utilization of air cooling appear greater than at steam-electric plants. A commercial plant (250 million standard cubic feet/day) relying on evaporative cooling could consume about 45,000 Ac. Ft/Yr. Recent estimates for plants which would utilize a dry cooling system amount to about 8,000 Ac.Ft./Yr. With such a large range, site specific data are important in preparation of regional water requirement estimates, a factor lacking at this time.

\section{d. Steam-Electric Generation Plants}

There are over 150 large thermal electric generating plants (those with generating units greater than $100 \mathrm{MW}$ ) in the West with an aggregate capacity of 40,039 MW. Numerous plants with smaller generating units comprise an additional aggregate capacity of 10,000 MW.

Firm plans exist to construct 85 additional large thermal electric generating units by 
Figure II-3

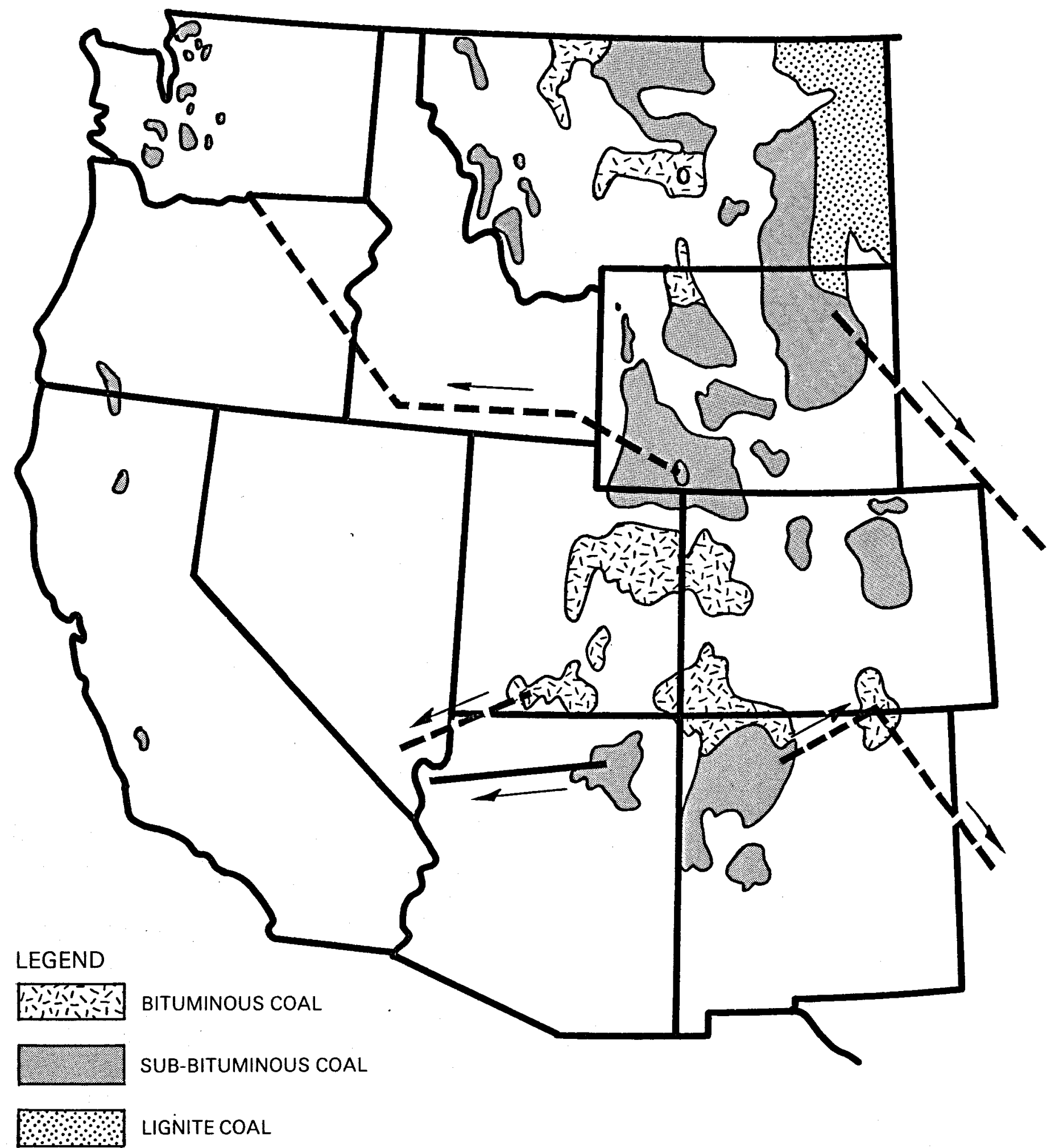

- $\boldsymbol{n}$ POTENTIAL PIPELINE EXISTING PIPELINE
Routing of Existing, Proposed and Planned Coal-Slurry Pipelines 
1986 in 46 locations, many of which already have existing generating units. The 85 new units are projected to have an aggregate generating capacity of $46,189 \mathrm{MW}$.

The April 1977 assessment of the Western States Coordinating Council (WSCC) is the source of these data. Member utilities, to ensure meeting future increases in demand, declare through this organization their intended construction schedules ten years in advance of operation.

Existing and planned large thermal electric generation plants in WSWC member states are shown in Figure II-4. Existing large steam-electric plants are listed in Tables A-1 through A-3 in Appendix A. A similar listing for planned plants, Tables B-1 through B-3, is contained in Appendix B. These tables list plants by name and location, planned methods of cooling, and the typical water consumption based on plant size.

The majority of existing plants plotted are oil. and gas fired (solid circles) and are located near load centers, with a significant grouping on the coast of Southern California. In general their construction occurred when oil and gas fuel supply availability was firm and opportunities for low cost cooling systems utilizing sea water were not, at the time of construction, faced with the complexities that now exist.

Plans for future plants, on the other hand, reflect an emerging dependence on Western coal resources as a result of the basic need for an assured fuel supply and licensing difficulties which have been encountered with proposed nuclear fueled facilities.

Plans for future energy facilities show a diminution in reliance on nuclear fuel, compared to plans made prior to 1974 . Nuclear plant construction costs now exceed $\$ 1$ billion per 1,000 MW unit with construction schedules extending over ten to twelve years. For a utility that is uncertain of its future demands ten years hence, it is difficult to make a decision to incur the billion dollar obligation.

Schedules for all of the coal-fired and nuclear plants have changed since 1974. Nuclear plant schedules have slipped and a number that were proposed have been cancelled. Figure II-5 compares 1974 total Western generation capacity plans with those now planned. Nuclear plant capacities in the predictable future in the West are no longer expected to equal those of coal-fired plants. The schedules, displayed in Figure II5, are probably reasonably accurate to 1984 . Relative stability of fuel prices beyond that date could be expected to maintain the same, or an even greater lead by the coalfired plants.

\section{Steam-Electric Plant Cooling Water Consumption}

Steam-electric plants rely on the Rankine cycle to produce electricity from heat energy. The efficiency with which the generated steam can be used is directly related to how well the low pressure side of the turbine can be cooled. Figure II- 6 shows a schematic of essential components of steam-electric plants.

Condenser cooling can be accomplished by any of the following:

(1) Once-through passage of large quantities of seawater or freshwater from a stream or large lake.

(2) Passage of large quantities of water circulating through a cooling pond.

(3) An evaporative cooling tower.

(4) A "dry" system using air as the cooling medium, operating much like an automobile radiator.

(5) A combination of (3) and (4) known as a 


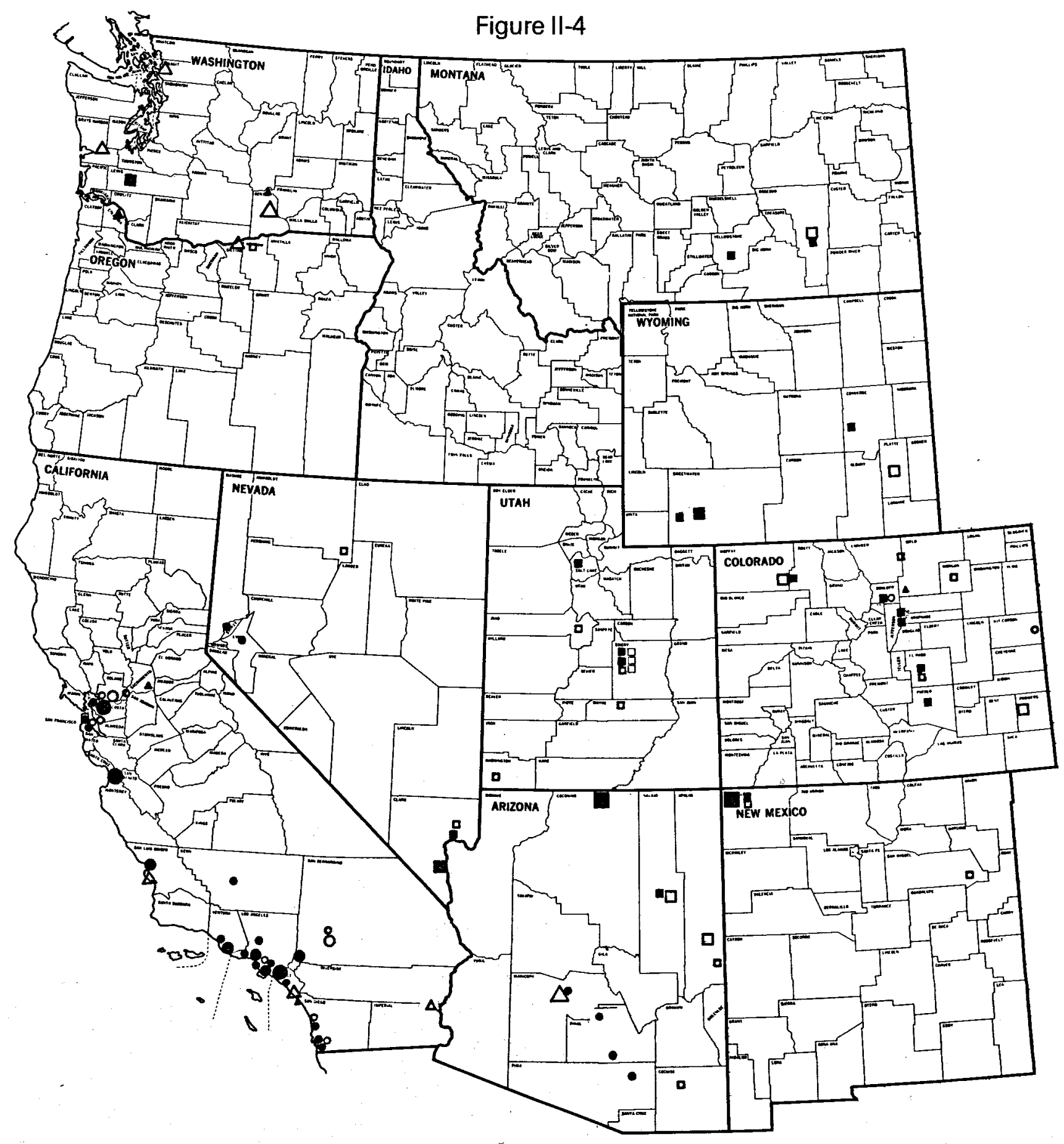

\begin{tabular}{|c|ccc|ccc|}
\hline RATING & \multicolumn{3}{|c|}{ EXISTING } & \multicolumn{3}{c|}{ PLANNED } \\
MEGAWATTS & OIL/GAS & COAL & NUCLEAR & OIL/GAS & COAL & NUCLEAR \\
\hline $100-1000$ & $\bullet$ & - & $\Delta$ & 0 & $\Delta$ & $\Delta$ \\
\hline $1000-2000$ & 0 & - & $\Delta$ & 0 & $\square$ & $\Delta$ \\
\hline $2000-3000$ & 0 & & $\Delta$ & 0 & $\square$ & $\Delta$ \\
\hline 3000 PLUS & 0 & & $\Delta$ & 0 & $\square$ & $\Delta$ \\
\hline
\end{tabular}

\section{Location of Existing and Planned} Steam-Electric Power Plants 
Figure II-5

Shift from Nuclear Towards Coal-Fired

Plants for Thermal Electric Generation

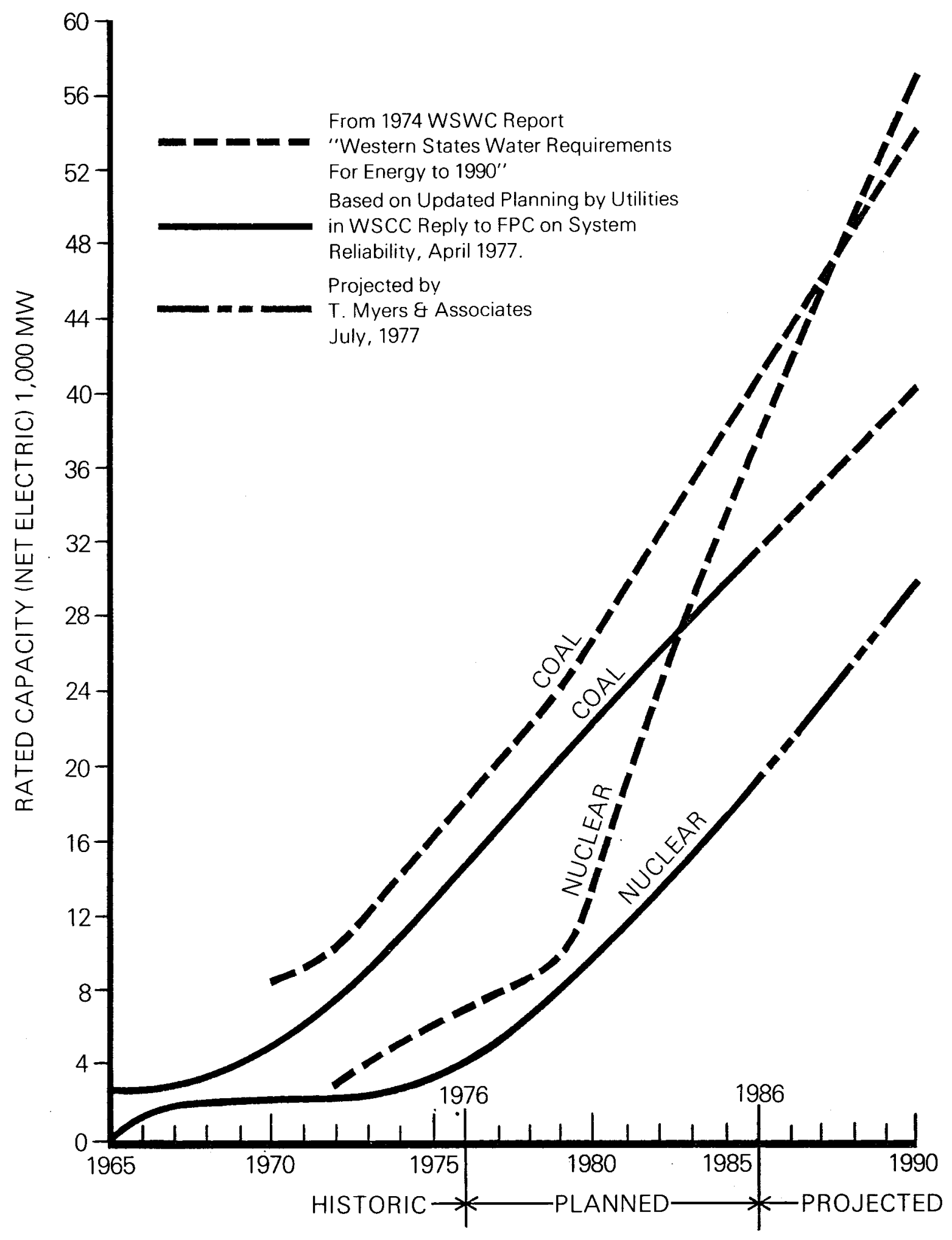


wet/dry cooling system.

The least expensive system, by far, is the once-through cooling system. Since utilities are obligated to produce electrical energy in the least expensive manner, the oncethrough system is the first to be considered. Water quality standards adopted under the Federal Water Pollution Act of 1972 have included stringent standards on thermal discharges to natural waters. Under these standards, utilities have encountered difficulties in acquiring permits for plant construction. To ensure meeting their obligations, utilities have directed their planning efforts toward more acceptable, although more expensive, cooling systems. Consumptive use of water in the oncethrough option occurs from evaporation of heated water, and is variable depending on plant site. Representative values, shown in Table II-3, are about 3600 to $4000 \mathrm{AcFt} / \mathrm{yr}$ per $1000 \mathrm{MW}$ unit.

The second least expensive alternative is use of a cooling pond. The simplest form is to construct a reservoir and to pass stored water through the plant's condenser in a manner similar to once-through cooling. Water consumption is a function of pond configuration and its attendant heat absorption characteristics. Representative. consumptive use values are in the 10,000 to $12,000 \mathrm{AcFt} / \mathrm{yr}$ per $1000 \mathrm{MW}$ range for cooling ponds.

Depending on the site, multiple use opportunities could be developed wherein diversion from a cooling pond could be made for other uses. The Boardman, Oregon, development is an example. Water will be pumped from the Columbia River to an off-stream pond for use in the coal-fired plant's once-through cooling system. Water also will be used from the pond for irrigation on adjacent lands. Cost sharing agreements have been developed whereby both the utility and the irrigators will achieve economies over other alternatives.

A more expensive alternative, and the choice which consumes the most water, is

Figure $11-6$

\section{Essential Components of Steam-Electric Plants}

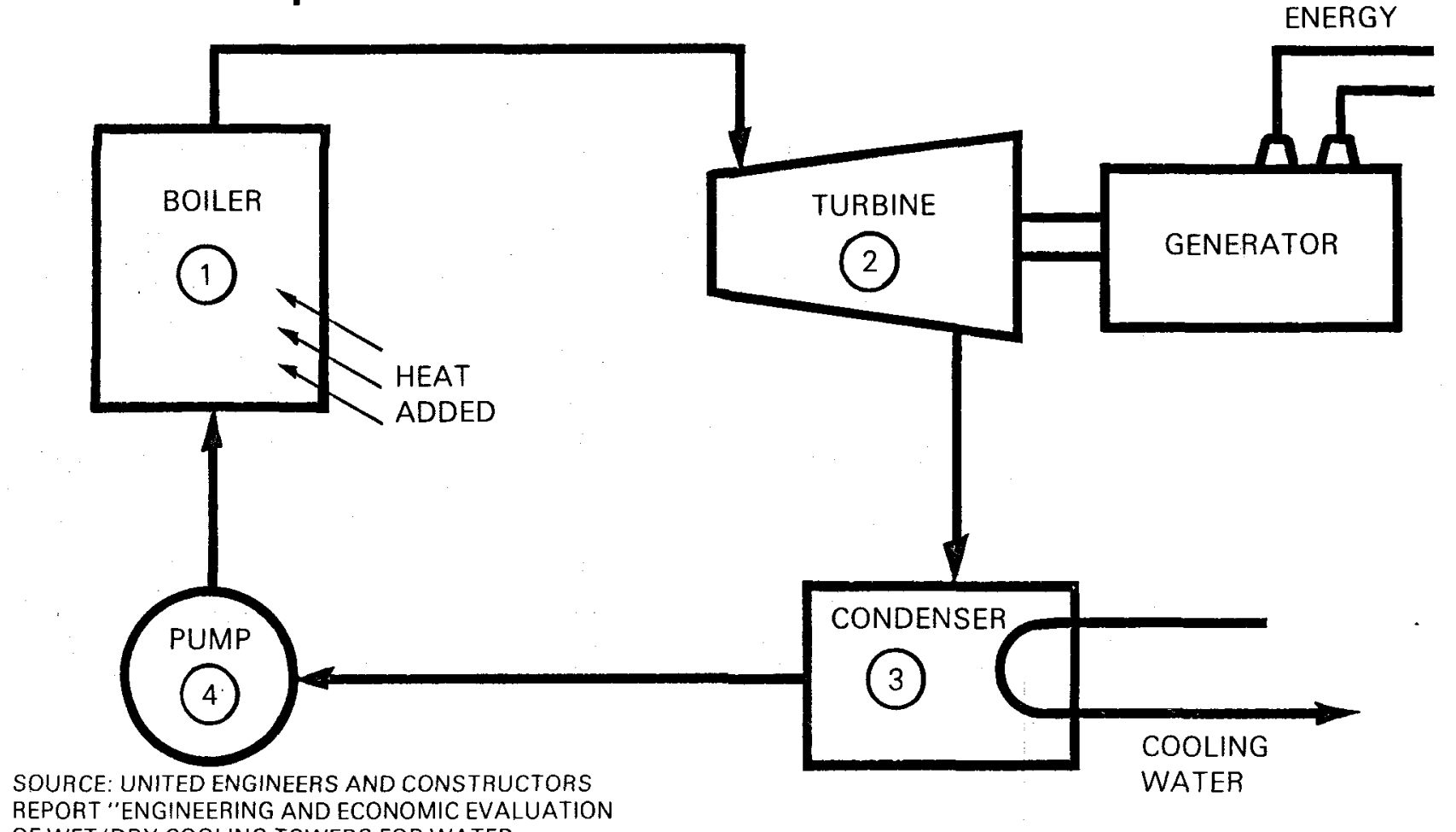


TABLE \|-3

\section{WATER CONSUMPTION RATES FOR VARIOUS ENERGY PROCESSES}

\section{Energy System}

Steam-Electric Nuclear

Evaporative Cooling

Pond

River

Wet-Dry Radiator

Steam-Electric Coal

Evaporative Cooling

Pond

River

Dry Radiator

Geothermal

Natural Gas

Crude Oil

Refineries

Oil Shale

Coal Gasification

Coal Liquification

Coal Slurry Pipeline

Coal Mining

Vegetation reestablishment
Water Needs

17,000 acre-ft/yr/1000mw unit
12,000 acre $\mathrm{ft} / \mathrm{yr} / 1000 \mathrm{mw}$ unit
$4,000 \mathrm{acre}-\mathrm{ft} / \mathrm{yr} / 1000 \mathrm{mw}$ unit
2,000 acre-ft/yr/1000mw unit

15,000 acre-ft/yr/1000mw unit 10,000 acre-ft/yr/1000mw unit $3,600 \mathrm{acre}-\mathrm{ft} / \mathrm{yr} / 1000 \mathrm{mw}$ unit 2,000 acre-ft/yr/ 1000mw unit

48,000 acre-ft ${ }^{\prime} y r / 1000 m w$ unit

50,000 acre-ft/yr throughout the West

50,000 acre-ft/yr throughout the West

$39 \mathrm{gal} / \mathrm{Bbl} / \mathrm{crude}$

7,600 to 18,900 acre-ft/yr/ 1000,000 BPD plant

8,000 to 45,000 acre-ft/yr/250 million SCF/day plant

20,000 to 130,000 acre-ft/yr/100,000 BPD plant

20,000 acre-ft/ 25 million tons coal

(1 cfs will transport about 1,000,000 tons per year)

.5 to 4 acre-ft/acre/yr (some areas may require two years) 
the evaporating cooling tower. For a 1,000 MW coal-fired or nuclear plant, an evaporative cooling tower will normally evaporate 15,000 to $17,000 \mathrm{AcFt} / \mathrm{yr}$ which is considered representative for estimates in this report. There is an additional requirement for "blowdown" to allow water to evaporate without excessive mineral deposits being formed in the tower which occurs when water is high in total dissolved solids (TDS). If the incoming water is low in TDS, the blowdown need be no more than 3,000 AcFt/yr for a 1,000 MW plant. If the incoming water is high in TDS, the blowdown may exceed 8,000 AcFt/yr. Each plant site has its own particular requirement for additional water such as for ash sluicing, revegetation, etc. Thus, water consumption for a 1,000 MW plant could total 20,000 to $25,000 \mathrm{AcFt} / \mathrm{yr}$; however because these values are dependent on site characteristics, these additional requirements are not included in regional water use estimates in this report.

Dry cooling systems, while placing very small demands on water supply are difficult to justify economically because they entail the largest capital costs along with increased operating costs attendant with lower efficiencies.

Some makeup water is necessary and a representative value has been found to be 2,000 AcFt/yr per $1000 \mathrm{MW}$ unit.

The only totally dry cooling system planned in the West is the Wyodak coalfired plant in Wyoming, rated at $330 \mathrm{MW}$ which is expected to become operational about mid-1978. The plant will utilize a high back-pressure turbine designed to match the cooling system, but overall plant efficiencies still will be less than those of more "conventional" plants. Because of the lower efficiency and attendant high costs, the plant probably is not an example of the plant of the future, although valuable operating experience will be gained.

More typical of what might be expected in the future in the West is the San Juan -3 plant under construction in the Four Corners area which will utilize parallel path (wet/dry) mechanically induced draft cooling towers.

Current plans for future thermal electric generation facilities reveal an increasing tendency to rely on evaporative cooling towers as illustrated by Figure II-7. The small increment shown for air cooling results from installation of the Wyodak plant, San Juan -3 and combustion turbines, all of which are expected to contribute a small portion of future generation capacity. The trend toward evaporative cooling towers will result in maximum water consumption compared with other systems.

Summary Tables II-4 and II-5 show steam-electric plant consumptive use by existing and planned generation facilities in each of the WSWC member states. Total freshwater consumption by steam-electric plants throughout the West is expected to reach about $888,000 \mathrm{AcFt} / \mathrm{yr}$ by 1986 , an increase of $588,000 \mathrm{AcFt} / \mathrm{yr}$ over present tevels.

Extrapolating thermal electric power production needs from 1986 to 1990 reveals the likely addition of another 15,000 MW of thermal generation capacity which, using values for evaporative cooling systems, results in a possible additional consumption of 240,000 AcFt/yr. Therefore, the total increase in steam-electric cooling water needs to 1990 is expected to be about $828,000 \mathrm{AcFt} / \mathrm{yr}$. This compares with a previously forecast increase in need of $1,337,000$ AcFt in the 1974 WSWC Water for Energy Report. 


\section{Figure II-7}

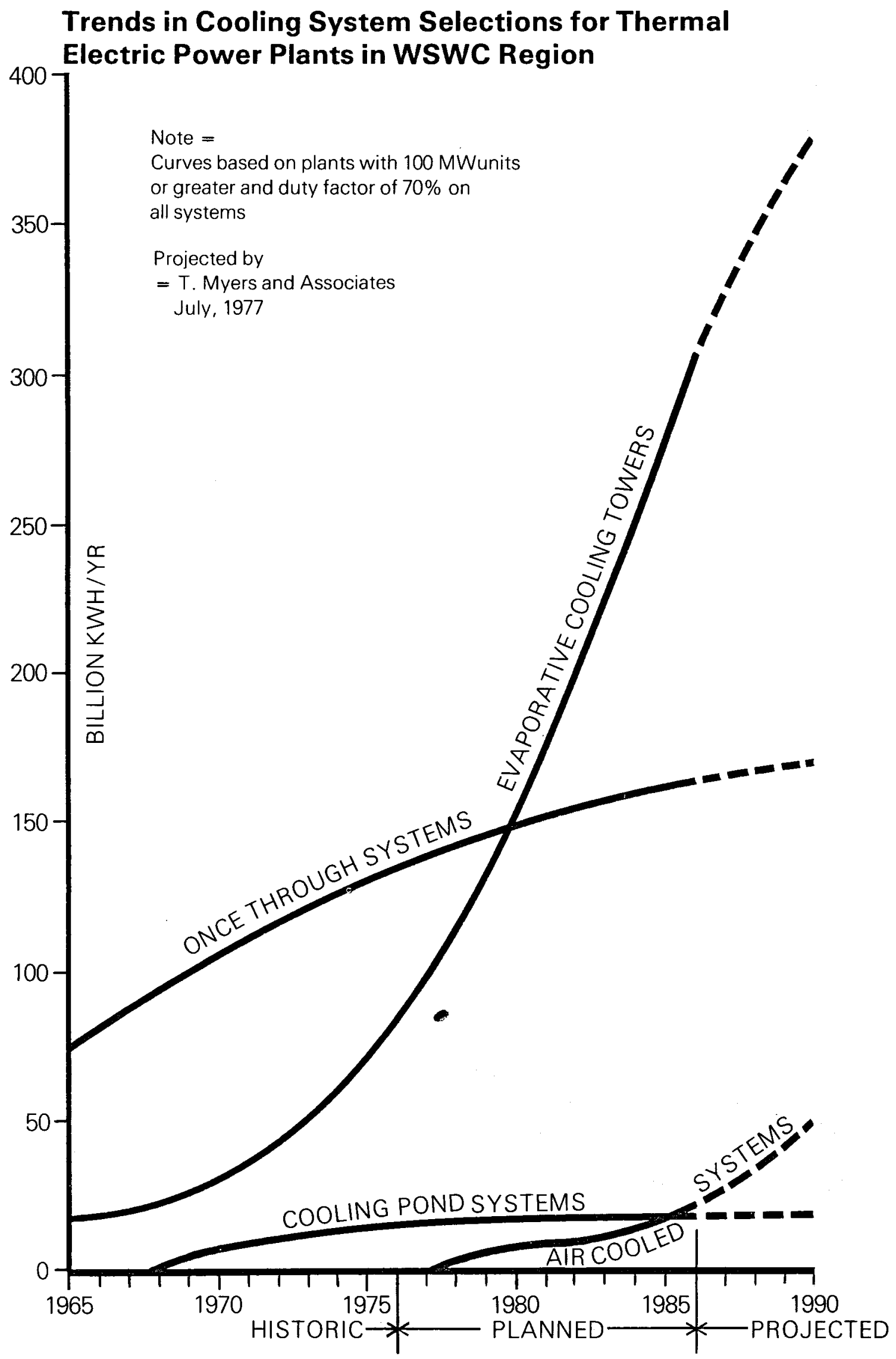


TABLE II-4

\section{STATE SUMMARY \\ CONSUMPTIVE USE BY EXISTING STEAM-ELECTRIC GENERATION AS OF 1976}

STATE

EXISTING OIL \& GAS-FIRED

Arizona

California

Nevada

Colorado

Montana

Nevada

New Mexico

Utah

Washington

Wyoming

California

Colorado

Oregon

\section{EXISTING COAL-FIRED}

EXISTING NUCLEAR
CONSUMPTIVE USE

Thous. AcFt/Yr
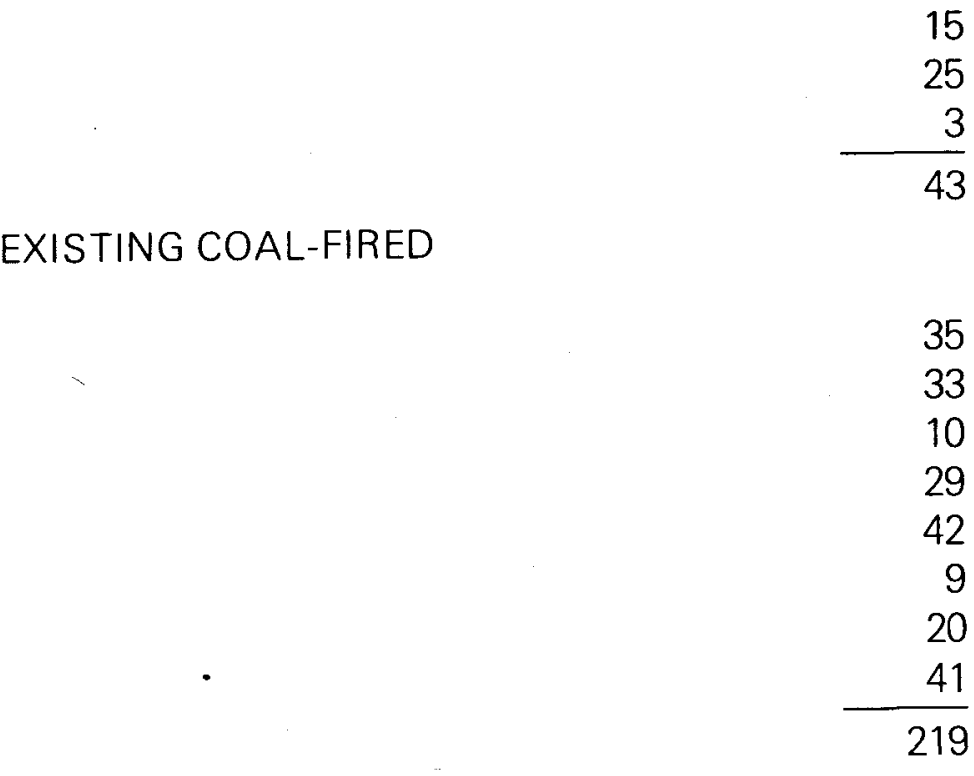

16

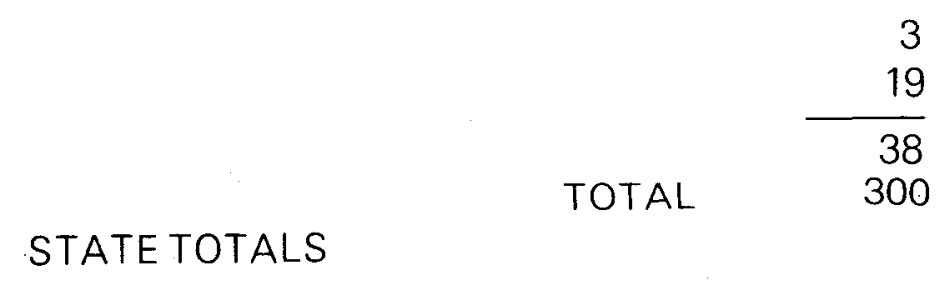

Arizona

California

50

Colorado

Idaho

Montana

Nevada

New Mexico

Oregon

Utah

Washington

41

36

Wyoming

TOTAL 
TABLE II-5

\section{STATE SUMMARY}

\section{CONSUMPTIVE USE BY PLANNED STEAM-ELECTRIC} GENERATION 1977 to 1986

STATE

California

Colorado

Arizona

California

Colorado

Montana

Nevada

New Mexico

Oregon

Utah

Wyoming

Arizona

California

Colorado

Oregon

Washington

Arizona

California

Colorado

Idaho

Montana

Nevada

New Mexico

Oregon

Utah

Washington

Wyoming
CONSUMPTIVE USE

Thous. AcFt/Yr

OIL \& GAS-FIRED

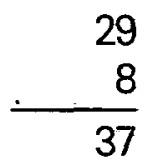

COAL-FIRED

NUCLEAR

63

33

6

43

147
292

TOTAL $\quad 588$

STATE TOTALS

101

86

68

$--$

21

15

16

51

56

147

27

TOTAL $\quad 588$

1987-1990 Increase over Region

Total 1990 Use by Generation Facilities

828 


\section{Water Use Considerations in Energy Development}

\section{A. Economic Considerations in Plant Cooling}

As discussed previously, in terms of capital costs, dry cooling systems rank highest among alternatives, followed by wet-dry systems, and then evaporative or all wet systems at the lower end. Examination of alternatives in regard to operating costs results in the same rank order.

The cost of water is a factor in cooling system selection analysis. A recent study 4 reviewing all cost data for three nuclear plant sites at various locations concludes that "for the range of reference sites it would require water costs in excess of $\$ 1$ to $\$ 2$ per thousand gallons $(\$ 330$ to $\$ 660$ per acre foot) before wet cooling towers would not be the economic choice" and that "water costs would have to approach the $\$ 13$ to $\$ 50$ per thousand gallon $(\$ 4200$ to $\$ 16,300$ per acre foot) range for air cooling to become competitive." A current overview study 5 summarizing other economic analyses conclude that the breakeven range for wet/dry cooling is $\$ 1.60$ to $\$ 2.50$ per thousand gallons. $(\$ 520$ to $\$ 815$ per acre foot) Thus; plant designers will be motivated to select evaporative cooling systems until water costs exceed about $\$ 660$ per AcFt. Above that value wet/dry systems would be attractive until water costs reach $\$ 4,200$ per AcFt, at which level an all dry system becomes feasible The same overview study includes a tabulation of relative costs of alternative cooling systems for a nuclear plant. Based on 1969 data, total unit costs in mills/KWH for selected cooling systems are:

$\begin{array}{lr}\text { COOLING SYSTEM TOTAL UNIT COSTS } \\ \text { Mills/KWH } \\ \text { Once through-River } & 0.168 \\ \text { Cooling Pond } & 0.219 \\ \text { Mechanical Draft Wet Tower } & 0.480 \\ \text { Mechanical Draft Dry Tower } & 0.618 \\ \text { Air Cooled Condenser } & 0.506\end{array}$

Most irrigation occurs in the West based upon an economy which includes water costs of $\$ 20$ per AcFt and less, although recent large scale private developments are paying more than twice that amount. Agricultural interests generally will not be able to compete for water supplies with thermal plant development. However, costs being paid by recent irrigation developments indicate that opportunities for cost sharing of joint facilities are probable. The previously cited overview study includes a brief examination of the approximate cost of acquiring a water supply by purchase of irrigated lands. The table below reproduces the results:

\section{COST OF WATER ACQUIRED BY PURCHASING IRRIGATED FARMS}

\begin{tabular}{|c|c|c|c|c|c|}
\hline \multirow[t]{2}{*}{ Case } & \multirow{2}{*}{$\begin{array}{l}\text { Land Cost } \\
\text { \$/Acre }\end{array}$} & \multirow{2}{*}{$\begin{array}{c}\text { Ft. of Water } \\
\text { Per Acre }\end{array}$} & \multirow{2}{*}{$\begin{array}{l}\text { Irrigation } \\
\text { Efficiency }\end{array}$} & \multicolumn{2}{|c|}{ Capitalized Cost } \\
\hline & & & & \$/Ac. Ft. & $\$ / 1000 \mathrm{gal}$ \\
\hline A & 2000 & 4 & $60 \%$ & 88 & 0.27 \\
\hline B & 4000 & 4 & $70 \%$ & 151 & 0.46 \\
\hline C & 1500 & 3 & $40 \%$ & 132 & 0.41 \\
\hline D & 3000 & 4 & $50 \%$ & 159 & 0.49 \\
\hline
\end{tabular}

4 Future Needs for Dry or Peak Shaved Dry/Wet Cooling and Significance to Nuclear Power Plants, NP-150, Gen. Electric Co. for EPRI, February, 1976.

5 An Overview of Economic Legal and Water Availability Factors Affecting the Demand for Dry and Wet/DRY Cooling for Thermal Power Plants, Paul L. Hendrickson, Baltelle Northwest, June, 1977. 


\section{B. Alternative Water Supplies}

Water supplies from other than conventional surface or ground water sources have been and are being investigated. Two projects are underway in the West to evaluate use of return flows of two types as cooling water supplies.

A developmental project started in mid1975 with the objectives of determining costs of treating large quantities of water no longer suitable for agricultural use to a level usable in cooling towers and to assess the effect of those costs on utility rates. Data will be obtained from construction and operational field testing of a $5000 \mathrm{gpd}$ capacity plant using ion exchange softening and evaporative techniques. The stateutility sponsored project located near Firebaugh, California is scheduled over a three year period and is funded for $\$ 600,000$.

In a similar kind of effort the Arizona Nuclear Power Project will treat 60,000 gpm of sewage effluent for cooling the Palo Verde nuclear plant near Phoenix. The project will utilize a two-stage lime clarification process and will pipe the effluent 40 miles to the plant.

Such projects are noteworthy and can assist in achieving less reliance on conventional supplies, but economic justification may be difficult in other locations. In addition, the seasonal availability of agricultural return flows creates a need either for storage facilities, or seasonal use of another water supply, further increasing costs. Not only are costs a consideration, but in some areas water users depend upon and have valid rights to return flows from other users. Serious consideration must be given these alternatives because of their water conservation potentials.

6 Estimated costs for Bureau of Reclamation desalinization plant near Yuma, Arizona, using water with $3200 \mathrm{ppm}$ of dissolved solids in and $386 \mathrm{ppm}$ out and employing the
An alternative source of water that has attracted more attention in the past than now is desalinization of seawater. In 1968 it was estimated that desalinization of seawater would cost $22 \$ / 1,000$ gallons. More recent estimates for less saline water are closer to $80 \$ / 1,000$ gallons ( $\$ 260 / A c F t) .6$ Desalted seawater also would be available on demand, although delivery to an inland site would add substantially to costs.

\section{Iństitutional Considerations}

\section{State Water Law}

Water laws and associated institutions have been developed in each of the Western States. The existing institutions can be modified; as has been done in the past to meet new demands when it appeared appropriate and necessary.

Much of the water available for appropriation in the arid and semi-arid West has already been appropriated, and therefore supplies for new energy production will be obtained, to a certain extent, through sales and transfers of water rights from existing uses, principally agricultural.

Under the appropriation doctrine, which predominates in the western states, water rights may generally be sold and transferred, either with the sale of the land upon which the water is used, or separately. If the purchaser continues the same use at the same place of use, there is no problem beyond registering or filing a record of the transaction. However, state water codes generally require that any change in the point of diversion, place or purpose of use, either on a permanent or temporary basis, receive the approval of the state administering agency.

The considerations of the state engineer in making this determination differ from

membrane process. The $22 \% / 1,000$ gallons quoted in 1968 was a distillation process using vertical tube evaporators. 
state to state, but the rule applied in all western states is that other water rights, including those which depend on return flow, must be protected.

The sometimes substantial legal and engineering costs associated with a transfer are not seen as a significant impediment in acquiring water for the production of energy. In the first place, the dollar return for water use for energy production is much higher than it is in many other uses, such as in irrigation agriculture where water is often priced at less than $\$ 20$ per AcFt. Moreover, even if the price of water increased substantially, the percentage that water costs bear to all costs associated with energy production would remain low. When this is coupled with a policy which permits these costs to be incorporated in the price and passed along to the consumer, the price of water, even if increased substantially, would not have significant effects on the amount of water used for energy production.

Legal considerations will play an important role in determining the water available for energy production. As already noted, a major consideration will be the effect of the proposed transfer on existing rights. In addition, state policies and priorities relating to the utilization and management of the waters of the state may be determinative.

Such priorities may range from a simple declaration that in times of shortage domestic uses shall prevail over agricultural uses, to a very lengthy agenda of policies which emphasizes the affording of protection to the environment as part of a water resources management program. Thus, factors other than the impact on other water rights, to be considered by a state water rights administrator in determining an application to transfer water rights for energy production, could include the following: (1) water conservation measures implemented in the area to be served by the transfer; (2) availability of alternative sources of water supply, including reclaimed water; (3) specific steps to be taken to assure that water will be diverted and used in the most efficient manner to minimize possible waste and compatibility of the proposed use of water with water quality laws for the basin involved; (4) whether the proposed change is in the public interest; and (5) effects the proposed transfer will have on the environment.

Some states forbid the transfer of water rights apart from the land to which the right is appurtenant. Others forbid an irrigation district to transfer its water right to a use outside the district. In one case, changes from agricultural to industrial use of more than 15 cubic feet per second are prohibited.

Thus, in some states the constraints of water laws involving water transfers are formidable with respect to obtaining. water for proposed energy development.

Decisions on issues regarding water allocations are properly the responsibility of the states. As noted in the WSWC's earlier report, "it would be poor economics and poor social policy to attempt to modify basic institutions for water allocation or seek a blanket solution of any kind. There appears to be no substitute for a careful consideration of problems arising from individual situations. State and local officials are often prepared to make decisions on individual situations. By such procedure, it is possible to balance economic, ecological, and national interest objectives in a context of a particular problem."

In some areas of the west, new water rights will be established within the frame- 
work of existing state institutions. These rights can be established: (1) in areas where the natural flow of surface streams has not yet been fully appropriated; (2) in areas where additional storage can be constructed so that during periods of high runoff water can be stored for later use; or (3) in areas where more expensive sources of water, such as deeper ground waters, waters that will require desalinization, or water that can be imported from some significant distance or lifted to higher elevations is available. In all of the Western states there are procedures available to the energy industry to rapidly and efficiently establish new water rights to the use of these unappropriated waters.

\section{State Siting Practices}

Seven of the member states of the Western States Water Council have agencies established for review and regulation of the construction and operation of energy facilities. Each state's legislation includes statements of policy which reflect the individual requirements and unique characteristics of the state.

Facilities requiring permits include plants designed for production of electricity, gas, liquid hydrocarbon products, oil and gas refineries, uranium enrichment, and others. Some states include facilities for nuclear storage or waste disposal facilities, underground reservoirs for natural gas, or any industry whose cost is at least 50 million dollars. Transmission lines and pipelines also are included. In short, states have responded where needs exist for regulation of energy production facilities.

Many states require utilities to submit long range plans, identifying facilities to be constructed within the subsequent ten years. This provision creates an opportunity for states to not only review proposals, but to integrate identified future needs into their water resource planning efforts. Opportunities for joint use may be explored through cooperative state-utility planning and considering water costs utilities are able to pay, water development projects which have been judged to be economically infeasible in the past should be re-evaluated.

\section{Environmental Considerations}

Water quality standards developed pursuant to the Federal Water Pollution Control Act Amendments of 1972 affect power plant siting in the WSWC member states. Standards involving the discharge of heated cooling water have been interpreted to generally preclude the use of once-through cooling facilities on all water bodies except the ocean. Consequently, the majority of facilities constructed since 1972 have resorted to evaporative cooling towers.

On a site specific basis, however, it may be possible for once-through cooling techniques to be utilized during times of the year when stream flows are at their greatest, thus allowing for dissipation of much of the annual waste heat load without harmful environmental impact. Appreciable water savings would result where once-through cooling could be used seasonally, and evaporative cooling towers used during the warmer months.

Waste water management plans are being developed by states under Section 208 of the Federal Water Pollution Control Act Amendments of 1972. The major emphasis of these planning activities has been on management of municipal wastes and planning for waste water treatment facilities. As data are acquired on the assimilation capacities of streams it may 
become possible to identify locations where discharge of waste heat could be accomplished without exceeding standards.

The Coastal Zone Management Act of 1972 has fostered natural resource inventory and planning activities in the three coastal states that are members of WSWC. State programs have been developed for coastal zone management which are integrated into the energy facility siting agency's programs. Energy production facility siting opportunities have been narrowed as many coastal areas have been identified as possessing fragile environments or other values such that preservation has been selected as the most appropriate use.

\section{Water Conservation Opportunities}

Energy conservation can result in significant delay in the need for additional energy production facilities and attendant water demands. If the accepted growth rate in total energy demands were to be reduced by one percent, the 1990 demand for electrical energy would be reduced by about 5,000 MW. Assuming this capacity to be cooled by evaporative systems, up to 75,000 $\mathrm{AcFt} / \mathrm{yr}$ would then not be required. Water savings resulting from energy conservation can be significant in the West.

Major amounts of water would not be required if once-through cooling could be utilized by western energy developments. When typical rates shown inf Table II-3 are applied in the case of a 1,000 MW coal-fired unit $5000 \mathrm{AcFt} / \mathrm{yr}$ would be conserved by the use of ponds versus an evaporative system and if once-through cooling from a river or large reservoir were possible, over $11,000 \mathrm{AcFt} / \mathrm{yr}$ could be saved. If 10 plants of the 85 now scheduled for installation by 1986 could be converted to these less consumptive cooling systems, 50,000 to 100,000 AcFt would then be available for other uses.

Pursuit of these opportunities appears justified, based on conclusions presented by staff members of the lowa Institute of Hydraulic Research, summarized in the following: "The experience amassed to date at numerous power plants indicates that thermal pollution of water at the levels permitted by significantly relaxed standards, produces only minimal impact on the nearby aquatic communities. The price that the nation is paying, in terms of dollars, resource utilization, and water consumption, to take its waste-heat load off major water bodies is a very great one indeed, and in many instances appears not to be justified by the generally insignificant resulting environmental enhancement. Indeed, there are many instances in which the closed-cycle cooling systems likely impact the environment more adversely than would a well designed open-cycle system." Western streams wherein a cold water fishery exists should be given thorough study in a site specific basis, however, as existing temperature conditions may approach maximum tolerable levels.

As energy developments occur in the West, water requirements for the existing hydro-power system must continue to be a consideration. Consumptive uses upstream from a hydro-power installation reduce amounts of water available for generation. If, on the other hand, a hydro-facility is being operated under water rights senior to those of upstream users, state water administrators could be required to reduce junior diversions or to stop them altogether. These conditions become of increasing importance in low flow seasons, or in drought

7 Precis of remarks by John F. Kennedy, University of lowa, at the National Conference on Water, 23 May 1977. 
conditions such as those being experienced in 1977.

Additionally, in a multi-purpose facility, releases for other purposes during low water situations can reduce the amount of energy potentially available from the then existing storage or flows. Releases required for downstream flows may be necessary on a schedule which does not coincide with hydro-generation requirements. Use of other facilities such as fish ladders may become of primary importance thereby reducing amounts of water available for passing through generators.

Water use by steam-electric generation facilities can be an asset in terms of conjunctive operation with hydro stations, but water supplies for steam-electric facilities must be supplied on no less a firm basis than for a hydro-facility. Additionally, if water is not conserved at steam-electric plants it will have an adverse impact on Western hydro-power production. 
Start MW Rating cooling Water

Date Electl $\begin{gathered}\text { Cooling Ned } \\ \text { System } 10^{3} \text { a-ft }\end{gathered}$

ARIZONA

\begin{tabular}{ccccc} 
Saguaro Steam -1 & 1954 & 115 & ECT & 1.73 \\
Ocotillo Steam -1 & 1960 & 115 & ECT & 1.73 \\
-2 & 1960 & 115 & ECT & 1.73 \\
Agua Fria -1 & 1958 & 109 & ECT & 1.64 \\
-2 & 1957 & 109 & ECT & 1.64 \\
-3 & 1961 & 182 & ECT & 2.73 \\
Irvington Steam -3 & 1962 & 104 & ECT & 1.56 \\
-4 & 1962 & 156 & ECT & 2.34 \\
& \multicolumn{4}{c}{ CALIFORNIA } \\
\end{tabular}

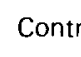

$-5 \quad 1966 \quad 480$

Huntington Beach-1 1958215

$\begin{array}{ll}1951 & 116 \\ 1951 & 116 \\ 1951 & 116 \\ 1953 & 117 \\ 1953 & 115 \\ 1964 & 340 \\ 1964 & 340\end{array}$

$1962 \quad 222$

$1961 \quad 232$

$$
1964220
$$

1964227

\section{4}

$1967 \quad 344$

$\begin{array}{ll}1954 & 175 \\ 1957 & 175\end{array}$

\section{$1967 \quad 480$}

\section{$1967 \quad 480$}

$1976 \quad 252$

1953132

$1953 \quad 132$

$1963 \quad 320$

$1963 \quad 320$

$\begin{array}{ll}1969 & 121\end{array}$

$1955 \quad 175$

$1956 \quad 175$

$1964 \quad 335$

$1965 \quad 335$

$1956 \quad 175$

$1957 \quad 175$

1961320

1962320

$1961 \quad 215$

1961225

1969121

1959215

1959215

$1970 \quad 121$

1971750

1973750
OT negl.

OT negl.

OT negl.

OT negl.

OT negl.

OT negl.

OT negl.

OT negl.

OT negl.

OT negl.

OT negl.

OT negl.

OT negl.

OT negl.

OT negl.

OT negl.

OT negl.

OT negl.

ECT 1.98

ECT $\quad 1.98$

ECT $\quad 4.80$

ECT $\quad 4.80$

ECT 1.82

OT negl.

OT negl.

OT negl.

OT negl.

or negl.

OT negl.

OT negl.

OT negl.

OT negl.

OT negl.

OT negl.

OT negl.

OT negl.

OT negl.

OT negl.

OT negl.

OT negl.

OT negl.

OT negl.

OT negl.
OT negl.

\begin{abstract}
Location
\end{abstract}
Red Rock, AZ

Tempe, AZ

Tempe, AZ

Glendale, $A Z$

Glendale, $A Z$

Glendale, $A Z$

Tucson, AZ

Tucson, AZ

Antioch, CA

Antioch, CA

Antioch, CA

Antioch, CA

Antioch, CA

Antioch, CA

Antioch, CA

Long Beach, CA

Long Beach, CA

Long Beach, CA

Long Beach, CA

Long Beach, CA

Long Beach, CA

Redondo Beach, CA

Redondo Beach, CA

Redondo Beach, CA

Redondo Beach, CA

Long Beach, CA

Etiwanda, CA

Etiwanda, CA

Etiwanda, CA

Etiwanda, CA

Etiwanda, CA

El Segundo, CA

El Segundo, CA

El Segundo, CA

El Segundo, CA

Long Beach, CA

Long Beach, $C A$

Long Beach, $C A$

Long Beach, CA

Long Beach, CA

Long Beach, $C A$

Long Beach, CA

Huntington Beach, $C$

Huntington Beach, $C$

Huntington Beach, $C$

Huntington Beach, C

Huntington Beach, $C$

Oxnard, CA

Oxnard, CA

Oxnard, CA

Oxnard, CA

Oxnard, CA

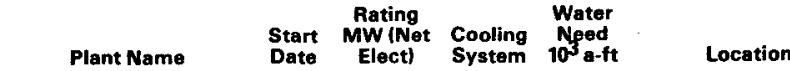

Encina -1
-2
-3
-4
South Bay -
-2
-3
-4

Kearny GT 1-3

Valley -1

$$
-2
$$

$-3$

$-4$

Date Eloct

Cooling $\begin{gathered}\text { Neod } \\ \text { System } \\ 10^{3} \mathrm{a}-\mathrm{ft}\end{gathered}$

1954100 OT negl. Carlsbad, CA

1956102 OT negl.

1958102 OT negl.

$\begin{array}{llll}1973 & 287 & \text { OT negl. }\end{array}$

1960140 OT negl.

1962. 142 OT negl.

1964198 OT negl.

1971220 OT negl.

1972183 Air none

$1954101 \quad$ ECT 1.52

$\begin{array}{llll}1954 & 101 & \text { ECT } & 1.52\end{array}$

$\begin{array}{llll}1955 & 171 & \text { ECT } & 2.57\end{array}$

$\begin{array}{llll}1956 & 160 & \text { ECT } & 2.40\end{array}$

Scattergood -1

$1958 \quad 179$

OT

negl.

1959179 OT negl.

$-2$

$$
-3
$$

1974309

Hunters Point -2

$1948 \quad 107$

$1949 \quad 107$

$1958 \quad 163$

OT

$$
-3
$$$$
-4
$$

Kern -2

Morro Bay -1

$$
\begin{aligned}
& -2 \\
& -3
\end{aligned}
$$

$-4$

$1950 \quad 106$

or

negl.

negl.

negl.

negl.

$1956 \quad 163$

OT

ECT

1.59

1955163

OT

1962338

OT

$1963 \quad 338$

Moss Landing - 1

$1950 \quad 116$

$1950 \quad 115$

$1951 \quad 117$

1952117

$1952 \quad 117$

$1967 \quad 739$

1968739

$1954 \quad 153$

$1954 \quad 163$

$1954 \quad 153$

$1954 \quad 163$

$1960 \quad 325$

1961325

$1972 \quad 720$

1965207

Potrero -3

Tracy -3

Ft. Churchill -1

$$
-2
$$

$$
\begin{aligned}
& 1974 \\
& 1968 \\
& 1971
\end{aligned}
$$

$1974 \quad 110 \quad \mathrm{CP}$

negl.

negl.

negl.

negl.

negl.

negl.

negl.

negl.

negl.

negl.

negl.

negl.

negl.

negl.

negl.

negl.

negl.

negl.

negl. 
TABLE A-2

WSWC REGION EXISTING COAL-FIRED ELECTRICAL GENERATION PLANTS

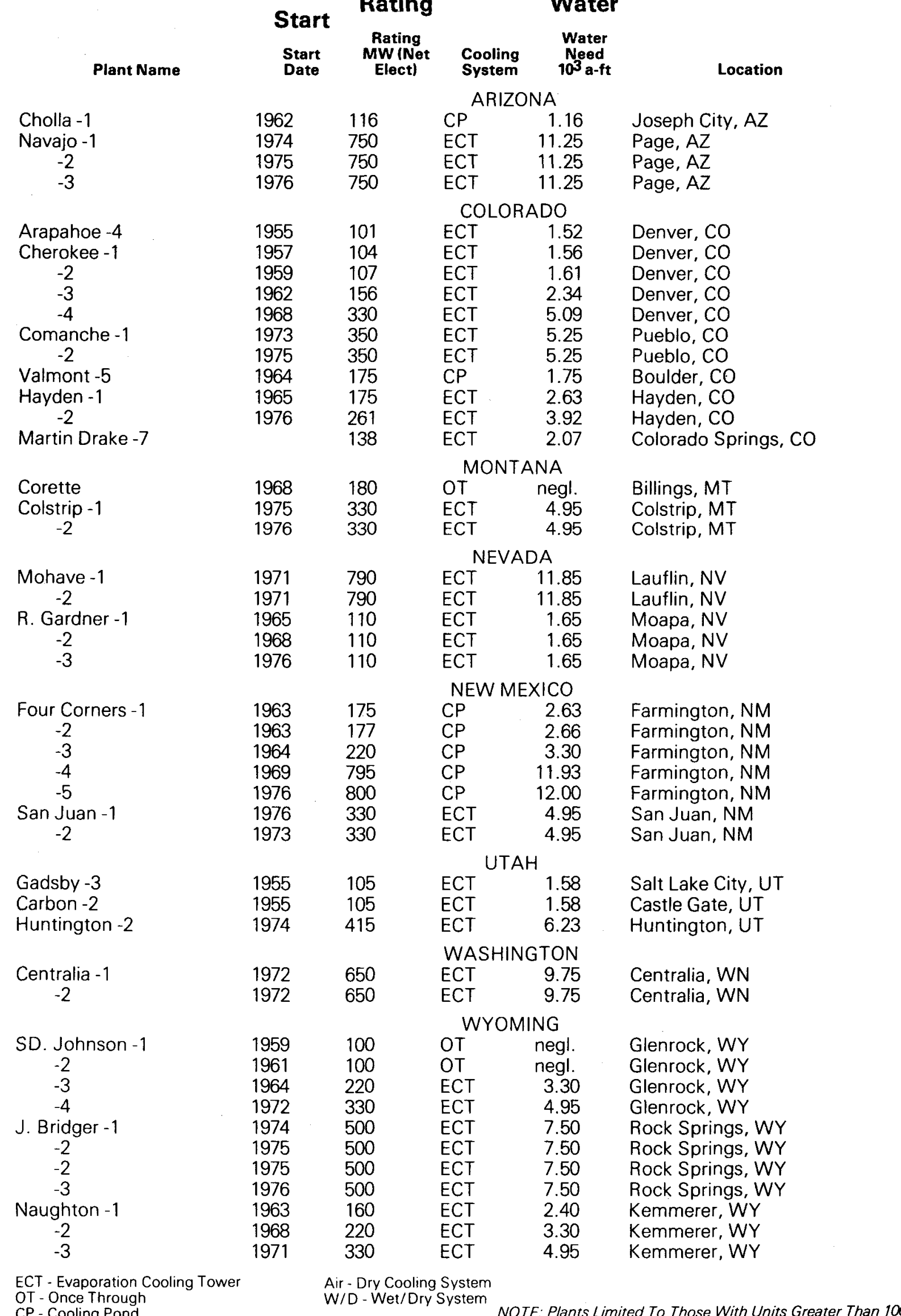

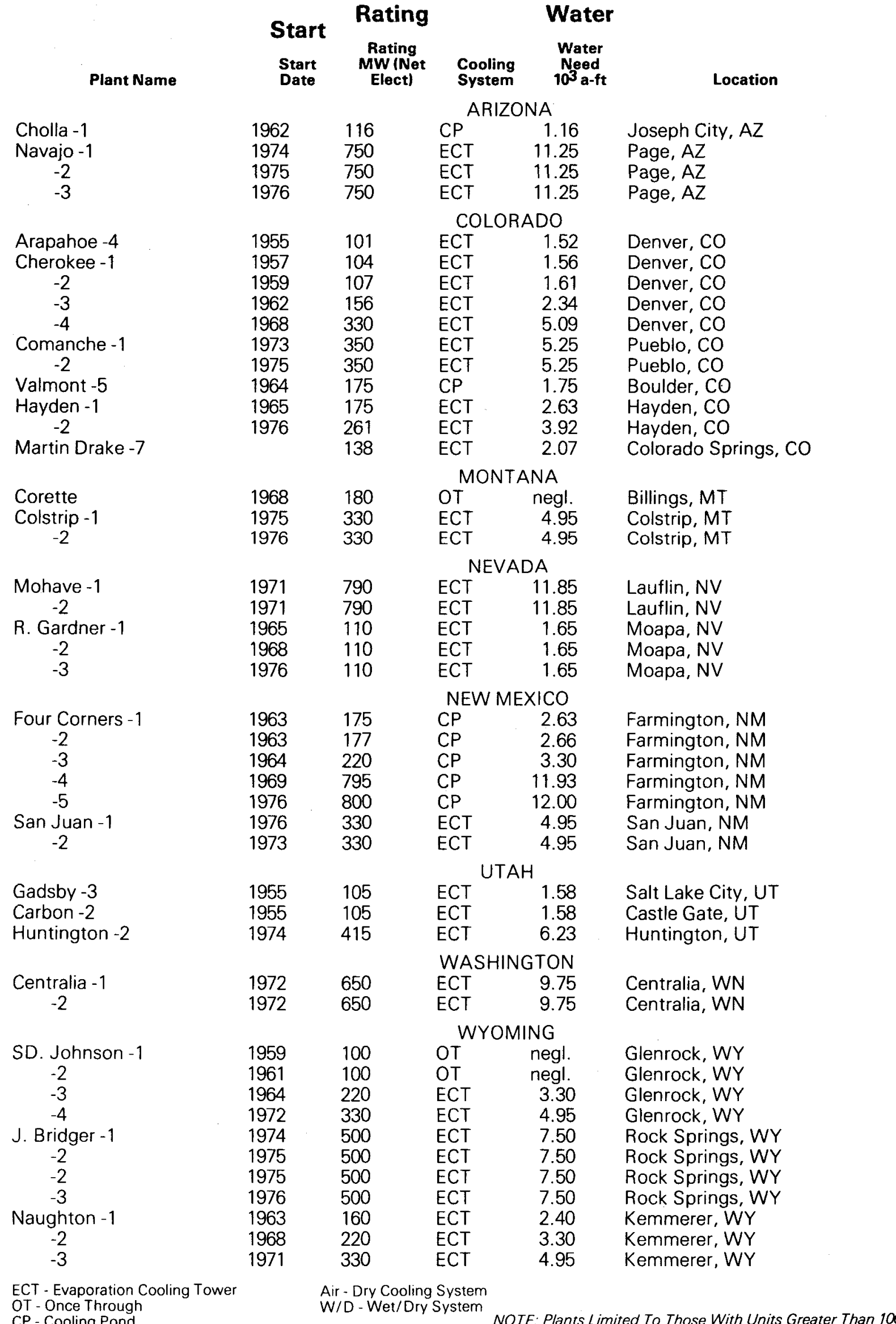

Water

OT - Once Through

NOTE: Plants Limited To Those With Units Greater Than $100 \mathrm{MW}$ 
TABLE A-3

WSWC REGION EXISTING NUCLEAR ELECTRICAL GENERATION PLANTS

\begin{tabular}{|c|c|c|c|c|c|}
\hline Plant Name & $\begin{array}{l}\text { Start } \\
\text { Date }\end{array}$ & $\begin{array}{c}\text { Rating } \\
\text { MW/Net } \\
\text { Elect }\end{array}$ & $\begin{array}{l}\text { Cooling } \\
\text { System }\end{array}$ & $\begin{array}{c}\text { Water } \\
\text { Need } \\
10^{3} \mathrm{a} \text {-ft }\end{array}$ & Location \\
\hline \multicolumn{6}{|c|}{ CALIFORNIA } \\
\hline San Onofre -1 & 1967 & 438 & OT & negl. & San Clemente, CA \\
\hline Rancho Seco -1 & 1975 & 913 & ECT & 15.52 & Sacramento, CA \\
\hline \multicolumn{6}{|c|}{ COLORADO } \\
\hline \multirow[t]{2}{*}{ St. Vain } & 1976 & 330 & ECT & 5.00 & Platteville, Colo. \\
\hline & \multicolumn{4}{|c|}{ OREGON } & \\
\hline \multirow{2}{*}{ Trojan } & 1976 & 1130 & ECT & 19.21 & Rainier, OR \\
\hline & \multicolumn{4}{|c|}{ WASHINGTON } & \\
\hline Hanford Gen. Plant & 1966 & 850 & OT & negl. & Hanford, WN \\
\hline \multicolumn{6}{|c|}{ ECT - Evaporative Cooling Tower } \\
\hline OT - Once Through & & NOTE & ts Limi & Those & iter \\
\hline
\end{tabular}




\section{APPENDIX B}

TABLE B-1

\section{WSWC REGION PLANNED OIL AND GAS-FIRED ELECTRICAL GENERATION PLANTS}

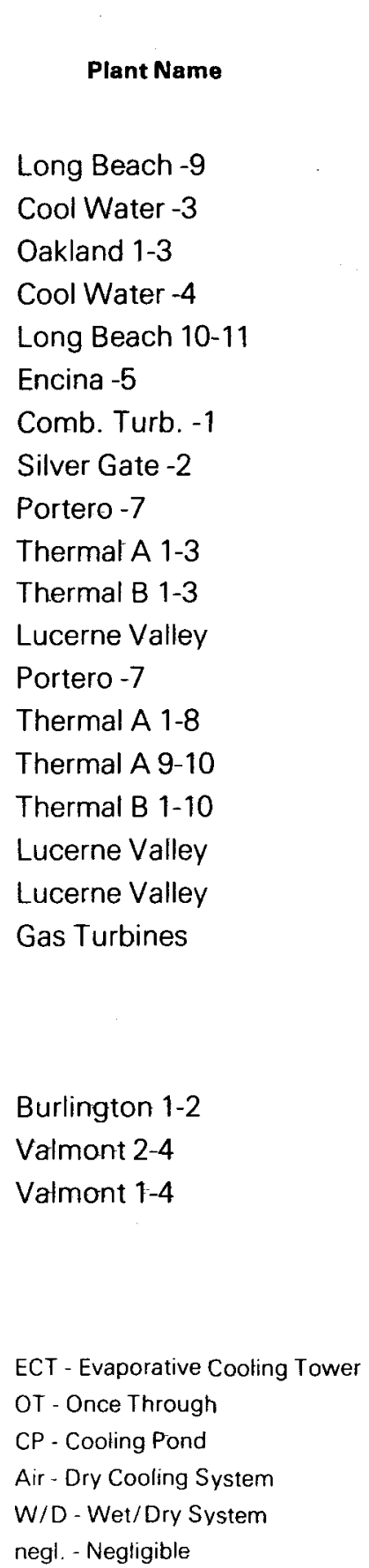

\begin{tabular}{|c|c|c|c|c|}
\hline $\begin{array}{l}\text { Start } \\
\text { Date }\end{array}$ & $\begin{array}{l}\text { Rating } \\
\text { MW (Net } \\
\text { Elect) }\end{array}$ & $\begin{array}{l}\text { Cooling } \\
\text { System }\end{array}$ & $\begin{array}{c}\text { Water } \\
\text { Need } \\
10^{3} \mathrm{a} \text {-ft }\end{array}$ & Location \\
\hline \multicolumn{5}{|c|}{ CALIFORNIA } \\
\hline 1977 & 238 & OT & negl. & Long Beach, CA \\
\hline 1978 & 236 & ECT & 3.54 & Dagget, $C A$ \\
\hline 1978 & 192 & OT & negl. & Oakland, CA \\
\hline 1978 & 138 & ECT & 2.07 & Dagget, CA \\
\hline 1979 & 112 & OT & negl. & Long Beach, CA \\
\hline 1979 & 292 & OT & negl. & Carlsbad, CA \\
\hline 1979 & 150 & $W / D$ & 1.35 & Sacramento, CA \\
\hline 1979 & 100 & ECT & 1.50 & San Diego, CA \\
\hline 1980 & 292 & Air & none & San Francisco, CA \\
\hline 1980 & 225 & Air & none & Bay Area, CA \\
\hline 1980 & 225 & Air & none & Bay Area, CA \\
\hline 1981 & 120 & Air & none. & Lucerne Valley, CA \\
\hline 1981 & 120 & ÖT & negl. & San Francisco, CA \\
\hline 1982 & 600 & ECT & 9.00 & Bay Area, CA \\
\hline 1982 & 200 & ECT & 3.00 & Bay Area, CA \\
\hline 1983 & 600 & ECT & 9.00 & Bay Area, CA \\
\hline 1984 & 180 & Air & none & Lucerne Valley, CA \\
\hline 1985 & 915 & Air & none & Lucerne Valley, CA \\
\hline 1986 & 385 & Air & none & Undetermined, CA \\
\hline
\end{tabular}

COLORADO

$\begin{array}{lllll}1977 & 102 & \text { ECT } & 1.53 & \text { Burlington, CO } \\ 1979 & 171 & \text { ECT } & 2.57 & \text { Boulder, CO } \\ 1981 & 228 & \text { ECT } & 3.42 & \text { Boulder, CO }\end{array}$

NOTE: Plants Limited To Those With Units Greater Than $100 \mathrm{MW}$ 
TABLE B-2

WSWC REGION PLANNED COAL-FIRED ELECTRICAL GENERATION PLANTS

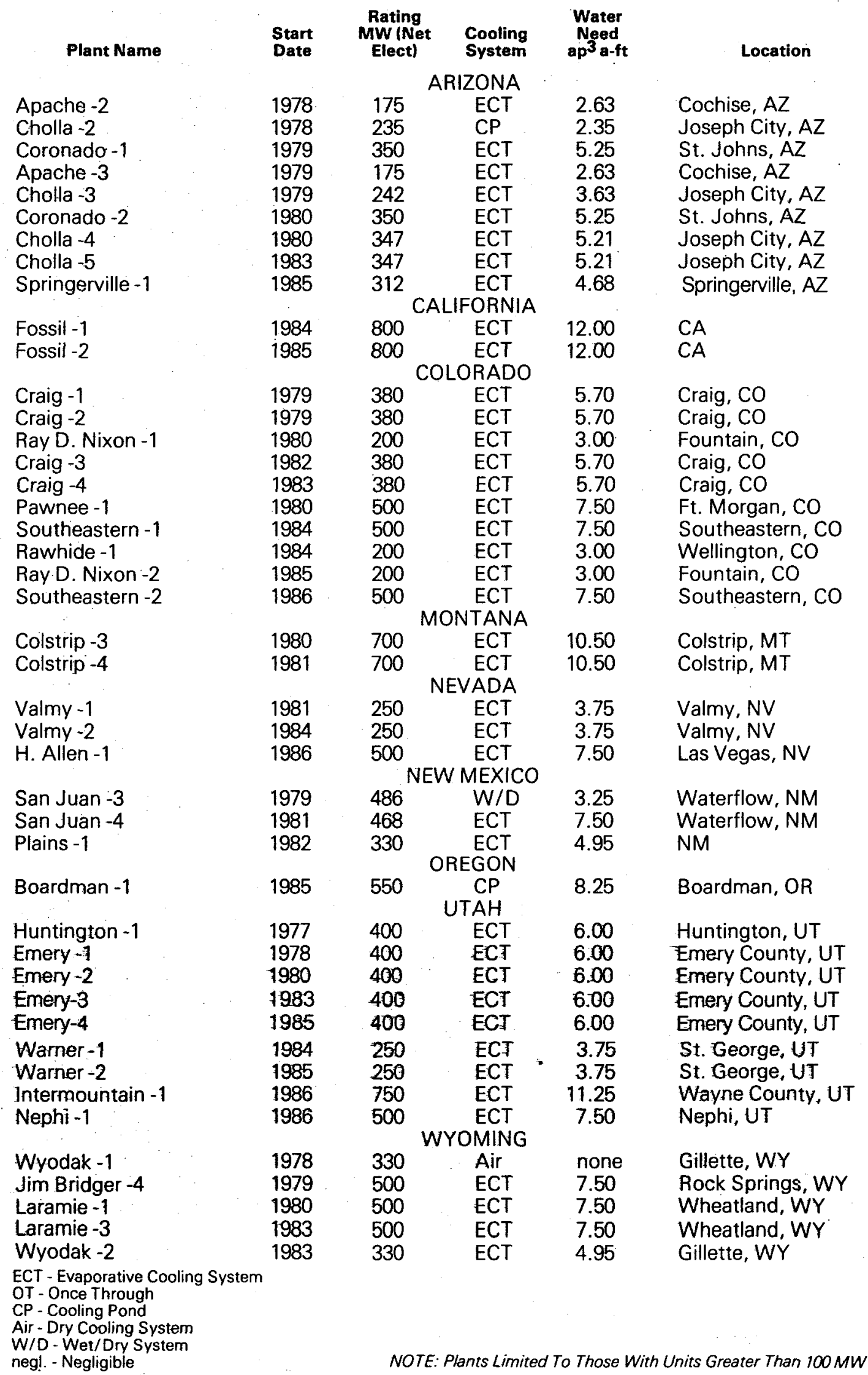


TABLE B-3

WSWC REGION PLANNED NUCLEAR ELECTRICAL GENERATION PLANTS

\begin{tabular}{|c|c|c|c|c|c|}
\hline Plant Name & $\begin{array}{l}\text { Start } \\
\text { Date }\end{array}$ & $\begin{array}{l}\text { Rating } \\
\text { MW (Net } \\
\text { Elect) }\end{array}$ & $\begin{array}{l}\text { Cooling } \\
\text { System }\end{array}$ & $\begin{array}{c}\text { Water } \\
\text { Need } \\
10^{3} \mathrm{a}-\mathrm{ft}\end{array}$ & Location \\
\hline \multicolumn{6}{|c|}{ ARIZONA } \\
\hline Palo Verde -1 & 1982 & 1235 & ECT & 21.00 & Wintersburg, AZ \\
\hline-2 & 1984 & 1235 & ECT & 21.00 & Wintersburg, AZ \\
\hline-3 & 1986 & 1235 & ECT & 21.00 & Wintersburg, AZ \\
\hline \multicolumn{6}{|c|}{ CALIFORNIA } \\
\hline Diablo Canyon -1 & 1977 & 1060 & OT & negl. & San Luis Obispo, CA \\
\hline-2 & 1977 & 1060 & OT & negl. & San Luis Obispo, CA \\
\hline San Onofre -2 & 1981 & 1100 & OT & negl. & San Clemente, CA \\
\hline-3 & 1983 & 1100 & OT & negl. & San Clemente, CA \\
\hline Sundesert -1 & 1984 & 974 & ECT & 16.56 & Blyth, CA \\
\hline-2 & 1986 & 974 & ECT & 16.56 & Blyth, CA \\
\hline \multicolumn{6}{|c|}{ COLORADO } \\
\hline Fort St. Vrain & 1977 & 330 & ECT & 5.61 & Platteville, CO \\
\hline \multicolumn{6}{|c|}{ OREGON } \\
\hline Pebble Springs -1 & 1985 & 1260 & ECT & 21.42 & Arlington, OR \\
\hline-2 & 1988 & 1260 & ECT & 21.42 & Arlington, OR \\
\hline \multicolumn{6}{|c|}{ WASHINGTON } \\
\hline WNP - 1 & 1981 & 1250 & ECT & 21.25 & Hanford, WN \\
\hline-2 & 1980 & 1100 & ECT & 18.70 & Hanford, WN \\
\hline-4 & 1983 & 1250 & ECT & 21.25 & Hanford, WN \\
\hline Skagit -1 & 1983 & 1288 & ECT & 21.89 & Sedro Wooley, WN \\
\hline-2 & 1986 & 1288 & ECT & 21.89 & Sedro Wooley, WN \\
\hline Satsop -3 & 1983 & 1240 & ECT & 21.08 & Aberdeen, WN \\
\hline-5 & 1985 & 1240 & ECT & 21.08 & Aberdeen, WN \\
\hline Hanford-1 & 1983 & (850) & OT & & Hanford, WN \\
\hline \multicolumn{6}{|c|}{$\begin{array}{l}\text { ECT - Evaporative Cooling System } \\
\text { OT - Once Through } \\
\text { CP - Cooling Pond } \\
\text { (1) - Planned Retirement } \\
\text { Air - Dry Cooling System } \\
\text { W/D - Wet/Dry System } \\
\text { negl. - Negligible }\end{array}$} \\
\hline
\end{tabular}

